\title{
Synthesis of $\left(2^{\prime}-5^{\prime}\right)$ Oligoadenylate and Activation of an Endoribonuclease in Interferon-Treated HeLa Cells Infected with Reovirus
}

\author{
TIMOTHY W. NILSEN, $\dagger$ PATRICIA A. MARONEY, $\dagger$ AND CORRADO BAGLIONI*
}

Department of Biological Sciences, State University of New York at Albany, Albany, New York 12222

\author{
Received 28 December 1981/Accepted 10 February 1982
}

\begin{abstract}
Treatment with interferon protected HeLa cells from infection with reovirus. This virus apparently activated an antiviral mechanism that was detected by the presence of $\left(2^{\prime}-5^{\prime}\right)$ oligoadenylate $\left[\left(2^{\prime}-5^{\prime}\right) A_{n}\right]$ in intact cells. The $\left(2^{\prime}-5^{\prime}\right) A_{n}$ was previously shown to activate an endoribonuclease, RNase L. We measured ( $2^{\prime}$ $\left.5^{\prime}\right) A_{n}$ by a sensitive competition-binding assay in cells infected at different multiplicities and for different lengths of time. Nanomolar concentrations of (2'$\left.5^{\prime}\right) A_{n}$ were detected in cells infected at a multiplicity of greater than 5 after $2 \mathrm{~h}$ of infection, the time at which the infecting virions were uncoated. The level of $\left(2^{\prime}-\right.$ $\left.5^{\prime}\right) A_{n}$ increased up to $6 \mathrm{~h}$ postinfection but declined afterward. To establish whether viral mRNAs were cleaved by RNase $L$, we analyzed the RNA extracted from infected cells by a highly specific hybridization assay on Northern blots. Full-sized reovirus mRNAs were detected in control infected cells, but not in interferon-treated infected cells, at $6 \mathrm{~h}$ postinfection. At this time, a nuclease activity could be detected in these cells by demonstration of cleavage of rRNA, degradation of cellular mRNA, and polysome breakdown in the presence of emetine. Since this inhibitor freezes ribosomes, cleavage of mRNA between ribosomes could only be accounted for by an endonuclease, presumably RNase L.
\end{abstract}

The antiviral state elicited by interferon (IFN) may result from distinct mechanisms (1). These include the synthesis of $\left(2^{\prime}-5^{\prime}\right)$ oligoadenylate $\left[\left(2^{\prime}-5^{\prime}\right) A_{n}\right](11)$ and the activation of a latent endoribonuclease (RNase $L)$ by $\left(2^{\prime}-5^{\prime}\right) A_{n}(2,5$, 20). This antiviral mechanism was initially studied in cell-free systems, but it was thought to operate in intact cells because $\left(2^{\prime}-5^{\prime}\right) A_{n}$ was isolated from IFN-treated $L$ cells that were infected with encephalomyocarditis virus (EMCV) [23]. More recently, elevated levels of $\left(2^{\prime}-5^{\prime}\right) A_{n}$ were found in these cells by a sensitive competition-binding assay (12), and activation of RNase $L$ was also shown by the detection of specific endonucleolytic cleavages of rRNA (24), similar to those previously reported to occur in interferon-treated, SV40-infected cells (21).

This antiviral mechanism is fairly well understood at the molecular level (1). IFN promotes synthesis of the $\left(2^{\prime}-5^{\prime}\right) A_{n}$ polymerase (or (2'$\left.5^{\prime}\right) A_{n}$ synthetase), which is only active when bound to double-stranded RNA (dsRNA) (10). The IFN-treated cells have elevated levels of the $\left(2^{\prime}-5^{\prime}\right) A_{n}$ polymerase, but this enzyme apparent-

\footnotetext{
† Present address: Department of Microbiology, Case Western Reserve University School of Medicine, Cleveland, OH 44106.
}

ly remains inactive until the cells are infected by an RNA virus which replicates by forming structures containing dsRNA. The $\left(2^{\prime}-5^{\prime}\right) A_{n}$ polymerase, for example, is activated by the replicative complexes of EMCV (17). The polymerase can also be activated by incubation of IFNtreated cells with the synthetic dsRNA polyinosinate-polycytidylate. The elevated levels of $\left(2^{\prime}-5^{\prime}\right) A_{n}$ found in these cells correlate with an elevated endonuclease activity and an enhanced turnover of cellular mRNA (18).

Our experiments were directed toward studying this antiviral mechanism in a system which did not have some of the drawbacks of other cell-virus systems. With most viruses, some replication is required to form viral structures containing dsRNA, which can activate the (2'$\left.5^{\prime}\right) A_{n}$ polymerase. Moreover, since viral RNA synthesis is drastically inhibited by treatment with IFN, it is difficult to follow the fate of viral RNA. To overcome such problems, we chose to infect HeLa cells with reovirus, which has a dsRNA genome. Reovirus is uncoated in infected cells and yields subviral particles which can activate the $\left(2^{\prime}-5^{\prime}\right) A_{n}$ polymerase (13). In IFNtreated cells that were infected at high mutiplicity with reovirus, we detected nanomolar concentrations of $\left(2^{\prime}-5^{\prime}\right) A_{n}$ and endonucleolytic cleavages of RNA. In these cells, cytoplasmic 
RNA is degraded, and full-sized viral RNA cannot be detected with a sensitive hybridization assay.

\section{MATERIALS AND METHODS}

Cells and treatment. HeLa cells were grown in suspension cultures and treated for $16 \mathrm{~h}$ with $200 \mathrm{U}$ of human fibroblast interferon per ml (HuIFN- $\beta ; 5 \times 10^{5}$ $\mathrm{U}$ per $\mathrm{mg}$ of protein; obtained from the Interferon Working Group of the National Cancer Institute) as previously described (18). Reovirus (Dearing type 3 ) was amplified on L929 cells and purified as described by Banerjee and Shatkin (3). For infection, HeLa cells were concentrated to $10^{7}$ cells per $\mathrm{ml}$ in medium without serum, infected for $60 \mathrm{~min}$ at $37^{\circ} \mathrm{C}$ with reovirus at the indicated multiplicity of infection (MOI), and diluted to $4 \times 10^{6}$ cells per $\mathrm{ml}$ in medium containing $5 \%$ fetal calf serum. To monitor viral RNA synthesis, we treated the cells with $5 \mu \mathrm{g}$ of actinomycin $\mathrm{D}$ per $\mathrm{ml}$ for $15 \mathrm{~min}$ before adding $10 \mu \mathrm{Ci}$ of $\left[{ }^{3} \mathrm{H}\right]$ uridine per $\mathrm{ml}$, as previously described (2).

Assay for $\left(2^{\prime}-5^{\prime}\right) A_{n}$ in cells. The extraction of nucleotides soluble in $5 \%$ trichloroacetic acid and the competition-binding assay were done exactly as previously described (18). This assay is a modification of that reported by Knight et al. (12).

Preparation of cDNA and Northern blot analysis. Reovirus mRNA was prepared by in vitro transcription with purified virions by the procedure of Both et al. (4). The DNA complementary to reovirus mRNA was prepared with reverse transcriptase by the calf thymus DNA fragments primer technique of Taylor et al. (22). Reaction mixtures $(0.1 \mathrm{ml})$ contained $0.8 \mathrm{mM}$ dGTP, $0.8 \mathrm{mM}$ dTTP, $0.8 \mathrm{mM}$ dATP, $50 \mu \mathrm{Ci}$ of $\left[\alpha-{ }^{32} \mathrm{P}\right] \mathrm{dCTP}(>1,000 \mathrm{Ci} / \mathrm{mmol}), 40 \mathrm{mM} \mathrm{KCl}, 10 \mathrm{mM}$ $\mathrm{MgCl}_{2}, 10 \mathrm{mM}$ dithiothreitol, $20 \mu \mathrm{g}$ of bovine serum albumin, $10 \mu \mathrm{g}$ of actinomycin D, $30 \mu \mathrm{g}$ of calf thymus DNA primer (prepared as described by Taylor et al. [22]), $1.8 \mu \mathrm{g}$ of reovirus mRNA, and $50 \mathrm{mM}$ Trishydrochloride buffer (pH 8.3). After $5 \mathrm{~min}$ at $0^{\circ} \mathrm{C}, 50 \mathrm{U}$ of avian myeloblastosis virus reverse transcriptase was added for $2 \mathrm{~h}$ at $37^{\circ} \mathrm{C}$. The reaction was stopped by the addition of $0.36 \mathrm{~N} \mathrm{NaOH}$, and the mRNA was hydrolyzed during a 4-h incubation period at $65^{\circ} \mathrm{C}$. The cDNA that was synthesized was purified by chromatography on Sephadex G-50 that was equilibrated with $0.5 \mathrm{M} \mathrm{NaCl}-1 \%$ sodium dodecyl sulfate $-20 \mathrm{mM}$ sodium acetate ( $\mathrm{pH}$ 6). Total cytoplasmic RNA was prepared from infected or mock-infected cells by phenol extraction. When indicated, the RNA was precipitated with $2 \mathrm{M} \mathrm{LiCl}$. The RNA was dissolved in water and lyophilized before the addition of $50 \%$ deionized formamide $-6 \%$ formaldehyde- $10 \%$ glycerol $-0.2 \mathrm{mM}$ EDTA in $0.02 \mathrm{M}$ sodium borate buffer ( $\mathrm{pH} \mathrm{8.3)}$. The RNA was heated for $15 \mathrm{~min}$ at $65^{\circ} \mathrm{C}$ and fractionated on $1.5 \%$ agarose gels by electrophoresis for $18 \mathrm{~h}$ at 80 $\mathrm{V}$ as described by Derman et al. (6). The gels were blotted on nitrocellulose sheets, which were then hybridized, washed, dried, and exposed to X-ray film (6).

Labeling and analysis of cellular mRNA. Cell cultures were treated for $\mathbf{3 0}$ min with $\mathbf{4 0} \mathrm{ng}$ of actinomycin $\mathrm{D}$ per $\mathrm{ml}$ and then incubated for $3 \mathrm{~h}$ with $10 \mu \mathrm{Ci}$ of $\left[{ }^{3} \mathrm{H}\right]$ uridine per $\mathrm{ml}$; the polyadenylate-containing RNA was isolated by chromatography on oligodeoxythymidylate-cellulose (18).
Polysome analysis. Cell extracts were prepared and sedimented on 15 to $40 \%$ sucrose density gradients for $90 \mathrm{~min}$ at $40,000 \mathrm{rpm}$ as described previously (18). The absorbance at $260 \mathrm{~nm}$ was monitored in a continuously recording spectrophotometer. Gradient fractions were pooled and precipitated with two volumes of ethanol after the addition of $0.25 \mathrm{M} \mathrm{NaCl}$. The precipitates were dissolved in $1 \%$ sodium dodecyl sulfate, and $\mathrm{LiCl}$ was added to a concentration of $2 \mathrm{M}$. They were then reprecipitated overnight at $-20^{\circ} \mathrm{C}$, redissolved, and centrifuged on 15 to $30 \%$ sucrose gradients for $19 \mathrm{~h}$ at $24,000 \mathrm{rpm}$; the fractions obtained were precipitated with $5 \%$ trichloroacetic acid for counting (18).

Assay for cleavage of rRNA. Total cytoplasmic RNA was prepared by phenol extraction from cells, as described above, or from cell extracts incubated according to the method of Nilsen and Baglioni (16). When indicated, the $0.1-\mathrm{ml}$ incubation mixtures contained $0.1 \mu \mathrm{M}\left(2^{\prime}-5^{\prime}\right) A_{n}$ prepared as described by Minks et al. (15). The incubations were done for 60 min at $30^{\circ} \mathrm{C}$. About $2 \mu \mathrm{g}$ of RNA was denatured and then fractionated on $1.8 \%$ agarose gels as described by McMaster and Carmichael (14).

\section{RESULTS}

In initial experiments, we established that HeLa cells are effectively protected from reovirus infection by treatment with IFN. Two parameters, cell viability and viral RNA synthesis, were examined (Fig. 1). Control cells died within $48 \mathrm{~h}$ of infection with reovirus, whereas IFNtreated cells remained viable. Cell division, however, was markedly inhibited in these cells, relative to IFN-treated mock-infected cells (Fig. 1a). The synthesis of viral RNA in IFN-treated cells was less than $5 \%$ of that in control cells (Fig. 1b). Subsequent experiments were de-

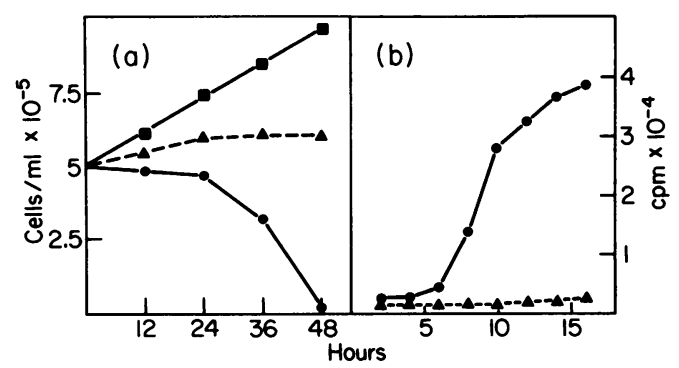

FIG. 1. Inhibition of reovirus replication in HeLa cells treated with IFN. Cells were either treated with $200 \mathrm{U}$ of IFN per ml $(\Delta)$ or not treated $(O)$ and were infected with reovirus at an MOI of 20 , as described in the text. (a) At the indicated times, cell samples were counted, and viability was determined by trypan blue exclusion; viable cells per milliliter are plotted. (b) Time course of reovirus RNA synthesis in the same cells. At the indicated times, samples of the cultures were incubated for $15 \mathrm{~min}$ with $5 \mu \mathrm{g}$ of actinomycin D per $\mathrm{ml}$ and then for $45 \mathrm{~min}$ with $10 \mu \mathrm{Ci}$ of $\left[{ }^{3} \mathrm{H}\right]$ uridine per $\mathrm{ml}$. The counts per minute (cpm) incorporated per $4 \times 10^{5}$ cells are indicated. The number of viable cells in an IFN-treated mock-infected culture is also indicated (). 
signed to investigate the mechanism responsible for this inhibition of viral RNA synthesis.

In view of the activation of RNase $L$ by $(2$ '$\left.5^{\prime}\right) A_{n}$ and the possible role of this endonuclease in the cleavage of viral RNA, we measured the $\left(2^{\prime}-5^{\prime}\right) A_{n}$ concentration in IFN-treated HeLa cells infected with reovirus. Extracts were prepared from cells infected for different lengths of time, and the $\left(2^{\prime}-5^{\prime}\right) A_{n}$ level was determined by a sensitive competition-binding assay (see above). Nanomolar amounts of $\left(2^{\prime}-5^{\prime}\right) A_{n}$ were found in these cells as early as $2 \mathrm{~h}$ postinfection; the amounts of $\left(2^{\prime}-5^{\prime}\right) A_{n}$ increased until about 6 $h$ postinfection but decreased afterward and were no longer detectable at $10 \mathrm{~h}$ postinfection (Fig. 2A). Less than $0.5 \mathrm{nM}\left(2^{\prime}-5^{\prime}\right) \mathrm{A}_{\mathrm{n}}$ was detected in a comparable sample of uninfected, IFN-treated HeLa cells, as previously reported (18), or in control cells infected with reovirus (data not shown). Both treatment with IFN and infection with reovirus are apparently required to promote synthesis of $\left(2^{\prime}-5^{\prime}\right) A_{n}$ in HeLa cells. Moreover, the amount of $\left(2^{\prime}-5^{\prime}\right) A_{n}$ found in these cells is related to the MOI. This was shown by infection of IFN-treated cells with reovirus at different MOIs and measurement of amounts of $\left(2^{\prime}-5^{\prime}\right) A_{n}$ at $6 h$ postinfection (Fig. 2B).

Reovirus mRNA in IFN-treated cells. The presence of $\left(2^{\prime}-5^{\prime}\right) A_{n}$ in IFN-treated cells infected with reovirus could result in the degradation of viral mRNAs. To detect these mRNAs and their cleavage products, we developed a highly specific and sensitive hybridization assay. The cytoplasmic RNA obtained from infected cells was fractionated by gel electrophoresis, blotted, and hybridized to highly radioactive DNA complementary to reovirus mRNAs prepared by in

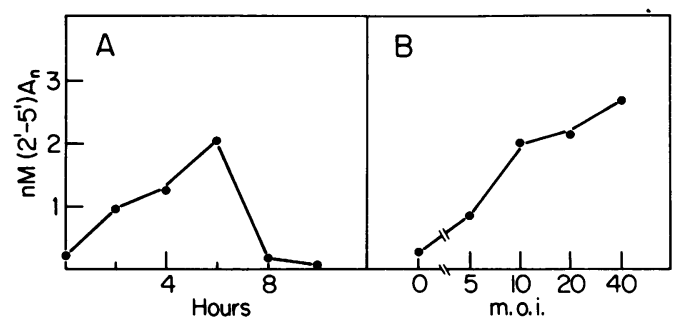

FIG. 2. $\left(2^{\prime}-5^{\prime}\right)$ Oligo(A) concentration in IFN-treated HeLa cells infected with reovirus as a function of the time postinfection and of the MOI. (A) Cells treated with $200 \mathrm{U}$ of IFN per ml were infected at an MOI of 20 with reovirus. Culture samples containing $10^{8}$ cells were taken at the indicated times postinfection. (B) Cells treated in the same way were infected with the indicated MOI reovirus, and culture samples containing $10^{8}$ cells were taken at $6 \mathrm{~h}$ postinfection. The $\left(2^{\prime}-5^{\prime}\right) A_{n}$ was extracted as described in the text, and its concentration was calculated per packed cell volume (about $0.4 \mathrm{ml}$ ).

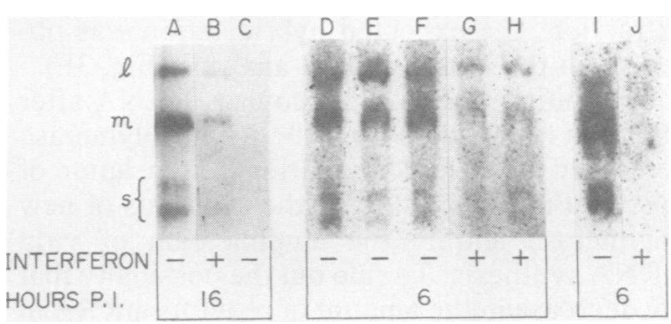

FIG. 3. Northern blot of reovirus RNA from IFNtreated or control HeLa cells. Control (A, D, E, and I) or IFN-treated cells $(B, G, H$, and $J)$ were infected with reovirus at an MOI of 20 . At the indicated times postinfection (P.I.), the cells were harvested, and the RNA was prepared and analyzed as described in the text. Tracks A and B contained 0.5 and $5 \mu \mathrm{g}$ of RNA, respectively; all of the other tracks contained $20 \mu \mathrm{g}$ of RNA. Track C contained mock-infected cells. Tracks $\mathrm{E}$ and $\mathrm{H}$ were prepared from cultures to which $0.1 \mathrm{mg}$ of emetine per ml was added at 2 h P.I. Track F contained control infected cells that were mixed with IFN-treated infected cells before RNA extraction. In tracks I and J, the RNA was precipitated with 2 M $\mathrm{LiCl}$ before analysis. The RNA was fractionated by electrophoresis on $1.5 \%$ agarose gels at $80 \mathrm{~V}$ for $16 \mathrm{~h}$. The different size classes of reovirus mRNA's ( $l$, large; $m$, medium; $s$, small) are indicated on the left.

vitro transcription. The validity of this assay was shown by the hybridization of the cDNA probe to RNA obtained from control cells infected for $16 \mathrm{~h}$ with reovirus. Four distinct bands were detected (Fig. 3A), two corresponding to the large and medium classes of reovirus mRNA and two corresponding to the small classes of reovirus mRNA (7). No hybridization was observed with the RNA of mock-infected cells (Fig. 3C). The same four bands were detectable, but were quite faint, in the RNA of IFN-treated cells infected for $16 \mathrm{~h}$ with reovirus (Fig. 3B). This confirmed that a greatly reduced amount of reovirus mRNAs was present in IFN-treated cells after several hours of infection.

In subsequent experiments, we investigated whether reovirus mRNAs were present in IFNtreated cells when the $\left(2^{\prime}-5^{\prime}\right) A_{n}$ concentration peaked at $6 \mathrm{~h}$ postinfection. In this analysis, we had to load a relatively large amount of RNA on the gels, because very little reovirus mRNA was synthesized in the first $6 \mathrm{~h}$ of infection (Fig. 1b). The separation of the bands hybridizing to the cDNA probe, therefore, was less satisfactory. However, the four bands corresponding to viral mRNAs were clearly seen in control infected cells (Fig. 3D), but were much fainter in IFNtreated infected cells (Fig. 3G). This finding could not be explained by the degradation of viral mRNAs during the extraction from IFNtreated cells, because when these cells were mixed with control infected cells before RNA 
extraction, the expected hybridization was observed in the Northern blot analysis (Fig. 3F).

The initial synthesis of reovirus mRNA after infection is carried out by the RNA polymerase contained in the infecting virions. Translation of this viral mRNA results in the synthesis of new polymerase and in the amplification of viral mRNA synthesis. To rule out the possibility that the decrease in the amount of reovirus mRNA in IFN-treated cells was caused by a defect in the translation of viral templates, we repeated the Northern blot analysis on RNA prepared from cells infected in the presence of an inhibitor of protein synthesis, emetine (9). In these cells, transcription of viral mRNAs is only carried out by the virion-associated polymerase. The amounts of reovirus mRNAs were only slightly reduced in control cells infected in the presence of emetine (Fig. 3E), indicating that protein synthesis is not required for transcription of viral mRNA during the first $6 \mathrm{~h}$ of infection. In IFN-treated cells infected in the presence of emetine, less viral mRNA was detected than in control infected cells; moreover, the pattern of RNA hybridizing to the cDNA probe seemed qualitatively different, with a diffuse background between the bands (Fig. 3H).

In these experiments, the genomic dsRNA of infecting virions was presumably present in the RNA preparations. Since the RNA was denatured before gel electrophoresis, the plus strand of the genomic dsRNA could hybridize with the cDNA probe. To avoid this problem, we removed by treatment with $2 \mathrm{M} \mathrm{LiCl} \mathrm{(16)} \mathrm{the}$ dsRNA from the RNA of cells infected in the presence of emetine. The hybridization in the blot of RNA prepared from control infected cells was almost unchanged (Fig. 3I), but we could not detect any full-sized viral mRNA in the blot of RNA prepared from IFN-treated infected cells (Fig. 3J). Therefore, the hybridization observed with the corresponding RNA sample that was not treated with $\mathrm{LiCl}$ (Fig. $3 \mathrm{H}$ ) was largely due to genomic reovirus dsRNA. These results are consistent with a degradation of reovirus mRNA in IFN-treated cells, although other explanations, such as a direct inhibition of transcription, cannot be ruled out at present.

Degradation of cellular mRNA. The experiments described above showed that nanomolar concentrations of $\left(2^{\prime}-5^{\prime}\right) A_{n}$ were present in IFNtreated cells infected with reovirus at MOI of greater than 5 (Fig. 2). The $\left(2^{\prime}-5^{\prime}\right) A_{n}$ activated RNase $\mathrm{L}$, which could cleave cellular mRNA. To measure the degradation of this mRNA, we labeled control and IFN-treated cells with $\left[{ }^{3} \mathrm{H}\right]$ uridine in the presence of $40 \mathrm{ng}$ of actinomycin D per $m l$ to inhibit rRNA synthesis (19). The polyadenylate-containing or polyadenylated RNA was then isolated at different times after infection by chromatography on oligodeoxythymidylate-cellulose (see above). Infection with reovirus resulted in enhanced decay of polyadenylated RNA in control cells only at an MOI of greater than 20, whereas it caused extensive degradation of this RNA in IFN-treated cells at an MOI of greater than 5 (Fig. 4). This decay was most pronounced between 3 and $6 \mathrm{~h}$ postinfection, when the concentration of $\left(2^{\prime}-5^{\prime}\right) A_{n}$ peaked (data not shown).

To establish that this decay was due to endonuclease activity, we examined the polysome patterns of control and IFN-treated cells infected with reovirus and treated with emetine. The breakdown of polysomes by an endonuclease was previously demonstrated in this way in experiments with cell extracts (15) and intact cells (18). Ribosome translocation, and therefore movement along mRNA, is inhibited by emetine (9); thus, polysome breakdown can only result from endonucleolytic breaks of mRNA. In our experiments, the cells were labeled as described above before infection with reovirus and treated with emetine from 2 to $6 \mathrm{~h}$ postinfection. Some change in the polysome pattern was observed in control infected cells, relative to control uninfected cells (Fig. 5). In IFN-treated cells, however, infection with reovirus caused an extensive conversion of polysomes to monosomes (Fig. 5).

To demonstrate that this conversion was due to endonuclease activity, we analyzed the RNA

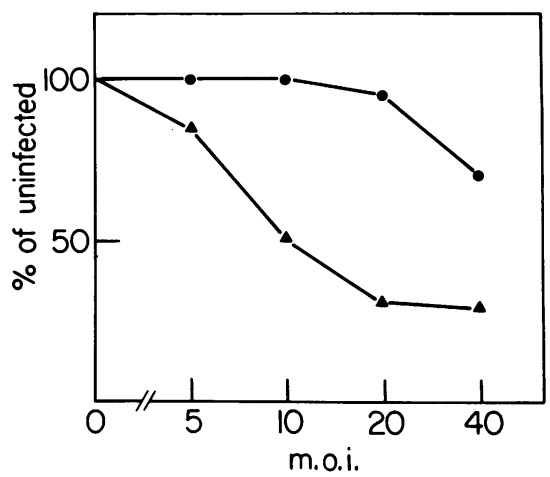

FIG. 4. Decay of cellular mRNA in IFN-treated cells as a function of the MOI with reovirus. Cellular mRNA was labeled in IFN-treated $(\Delta)$ and control $(\boldsymbol{O})$ cells by incubation for $3 \mathrm{~h}$ with $\left[{ }^{3} \mathrm{H}\right]$ uridine, as described in the text. The cells were then infected with the indicated MOI of reovirus. At $6 \mathrm{~h}$ postinfection, cell extracts were prepared from $4 \times 10^{6}$ cells, and the labeled polyadenylate-containing RNA was measured by oligodeoxythymidylate-cellulose chromatography. The amount of this RNA recovered is expressed as a percentage of that obtained from mock-infected cells $\left(4 \times 10^{4} \mathrm{cpm}\right)$. 


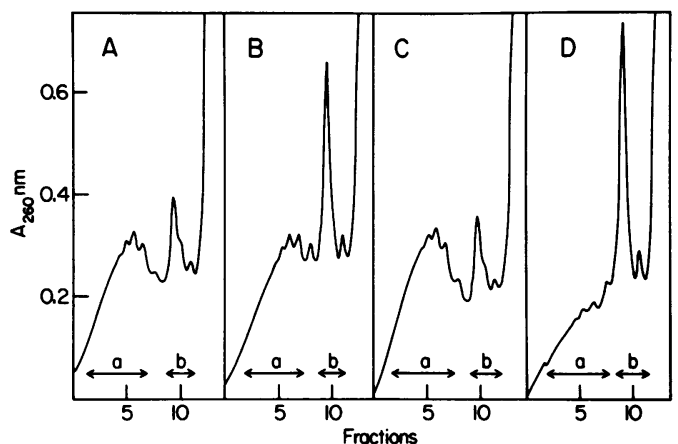

FIG. 5. Polysome breakdown in IFN-treated cells infected with reovirus. Control (A and B) and IFNtreated (C and D) cells were either mock infected (A and $C$ ) or infected with reovirus at an MOI of 20 (B and D). At $2 \mathrm{~h}$ postinfection, $0.1 \mathrm{mg}$ of emetine per $\mathrm{ml}$ was added. At $6 \mathrm{~h}$, cell extracts were prepared and fractionated by centrifugation on sucrose gradients (see text). Fractions corresponding to polysomes (a) or monosomes (b) were pooled and precipitated with ethanol. $A_{260} \mathrm{~nm}$, absorbance at $260 \mathrm{~nm}$.

of polysomes and monosomes by sedimentation on sucrose gradients. The sedimentation patterns of labeled RNA obtained from either control or IFN-treated uninfected cells were identical, with a broad peak of polysomal mRNA sedimenting around $18 \mathrm{~S}$ and a small peak of $4 \mathrm{~S}$ RNA in both polysomal and monosomal fractions (only the gradients of IFN-treated cells are shown in Fig. 6A and 6D). Slightly less RNA was recovered from polysomes of control infected cells (Fig. 6B) and, correspondingly, more slow-sedimenting RNA was found in the monosomal fraction (Fig. 6E). Much less RNA was recovered from polysomes of IFN-treated infected cells (Fig. 6C), and most of the RNA was found in the monosomal fraction (Fig. 6F). This RNA sedimented more slowly than polysomal RNA and was presumably mRNA degraded by endonucleolytic cleavages.

To show that the endonucleolytic activity was due to the activation of RNase $L$ by $\left(2^{\prime}-5^{\prime}\right) A_{n}$, we examined by gel electrophoresis the rRNA obtained from cells with elevated concentrations of $\left(2^{\prime}-5^{\prime}\right) A_{n}$ (Fig. 7). Wreschner et al. (24) have shown that rRNA is cleaved in IFN-treated L cells infected with EMCV and that the pattern of cleavage is similar to that obtained when ribosomes are digested in vitro with RNase L. We also detected cleavage of rRNA in IFN-treated HeLa cells infected with reovirus. This cleavage was dependent upon IFN treatment and infection, and the pattern of fragments obtained was similar to that generated in vitro by $R$ Nase $L$ (Fig. 7).

These results show that some rRNA and cellu-

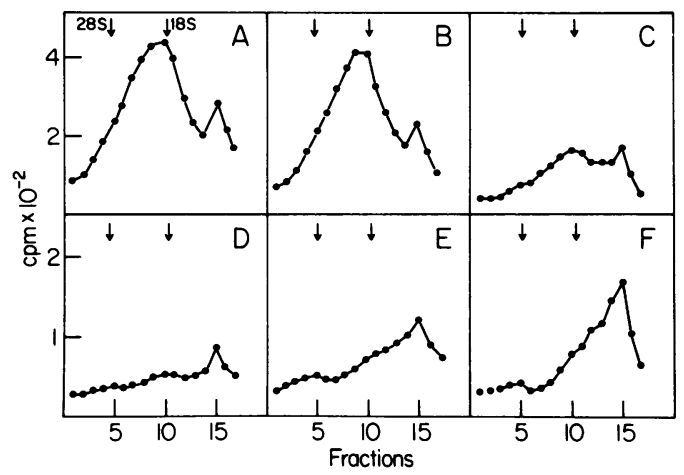

FIG. 6. Degradation of cellular mRNA in IFNtreated cells infected with reovirus. (A, B, and $C$ ) Fraction a from gradients B, C, and D of Fig. 5. (D, E, and F) Fraction b from the same gradients. The samples were analyzed by centrifugation on sucrose density gradients, as described in the text. The position of rRNA markers is indicated.

lar mRNA are degraded when nanomolar concentrations of $\left(2^{\prime}-5^{\prime}\right) A_{n}$ are formed in IFN-treated cells, but they also show that some mRNA degradation may occur in control cells infected with reovirus at a high MOI. It is possible that this mRNA degradation in control infected cells is due to RNase $L$ activation by $\left(2^{\prime}-5^{\prime}\right) A_{n}$ concentrations lower than $0.5 \mathrm{nM}$, which are unde-

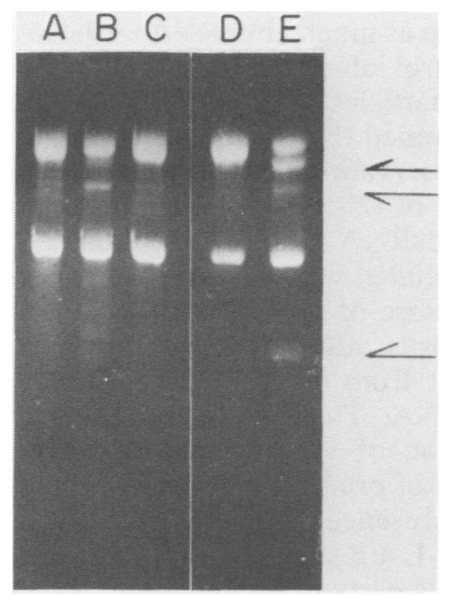

FIG. 7. Cleavage of rRNA in IFN-treated HeLa cells infected with reovirus. The RNA obtained from control HeLa cells (A) and cells treated with $200 \mathrm{U}$ of IFN per $\mathrm{ml}$ (B and C), either infected at an MOI of 20 with reovirus (A and $B$ ) or mock infected $(C)$, was analyzed as described in the text. The RNA obtained from cell extracts incubated without (D) or with 0.1 $\mu M\left(2^{\prime}-5^{\prime}\right) A_{n}(E)$ was analyzed at the same time. The gels were stained with acridine orange and photographed as described by McMaster and Carmichael (14). The major cleavage products of rRNA are indicated by the arrows. 
tectable in our assay, but could activate the RNase L.

\section{DISCUSSION}

Reovirus failed to replicate in IFN-treated HeLa cells. The infecting virus apparently activated an antiviral mechanism, indicated by the presence of $\left(2^{\prime}-5^{\prime}\right) A_{n}$. Synthesis of these oligonucleotides was correlated with the MOI and was presumably due to the activation of the $\left(2^{\prime}\right.$ $\left.5^{\prime}\right) A_{n}$ polymerase by the genomic dsRNA of infecting virions. This was suggested by the appearance of $\left(2^{\prime}-5^{\prime}\right) A_{n}$ early in the infection, at the time of the uncoating of infecting virions, a process which takes about 2 to $3 \mathrm{~h}(8)$. The concentration of $\left(2^{\prime}-5^{\prime}\right) A_{n}$ increased until $6 \mathrm{~h}$ postinfection, but it declined afterwards, possibly because of a gradual degradation of subviral particles containing genomic dsRNA. This explanation, however, remains to be investigated. After $6 \mathrm{~h}$ of infection, we could not detect fullsized reovirus mRNA in IFN-treated cells by a very sensitive hybridization assay. This finding may be accounted for by the cleavage of viral mRNA by RNase L; the cleavage products may be further degraded by other cellular nucleases. We cannot exclude, however, that an unknown antiviral mechanism directly inhibits the transcription of reovirus mRNA. This seems unlikely in view of the finding of Galster and Lengyel (8) that subviral particles prepared from IFNtreated $\mathrm{L}$ cells infected with reovirus could synthesize as much viral RNA as those prepared from control infected $L$ cells. The RNA made by subviral particles of IFN-treated cells, however, was degraded by endonucleolytic cleavages. These observations might be explained by the synthesis of $\left(2^{\prime}-5^{\prime}\right) \mathrm{A}_{n}$ by polymerase bound to reovirus dsRNA and the activation of RNase $L$, also associated with the subviral particles.

The failure of IFN-infected cells to accumulate reovirus mRNA early in the infection did not result from an inhibition of translation of viral mRNA. This failure resulted either from degradation of viral mRNA or from a direct inhibition of primary transcription. We propose that the presence of $\left(2^{\prime}-5^{\prime}\right) A_{n}$ and the activation of $R$ Nase $L$ are sufficient to limit the replication of reovirus early in the infection. This does not exclude other antiviral mechanisms that may play some role in the inhibition of reovirus replication under different conditions of IFN treatment or at different times after infection.

Measurable amounts of $\left(2^{\prime}-5^{\prime}\right) A_{n}$ were formed in IFN-treated cells infected with reovirus at an MOI of greater than 5 and, correspondingly, degradation of cellular RNA was observed under these conditions. Cells infected at an MOI of less than 5 were equally well protected by IFN; the presence of nanomolar concentrations of ( 2 ' - $\left.5^{\prime}\right) A_{n}$, therefore, was not required to obtain protection against reovirus. We have no direct evidence that $\left(2^{\prime}-5^{\prime}\right) A_{n}$ is formed and that viral mRNA is cleaved by RNase L in IFN-treated cells infected at an MOI of less than 5, but we believe that this antiviral mechanism may inhibit the replication of reovirus in these cells. This belief is based on in vitro experiments with the replicative intermediate of EMCV and model substrates containing RNA covalently linked to dsRNA (16). When the replicative intermediate of EMCV is incubated with extracts of IFNtreated cells, the nascent RNA strands linked to the dsRNA core of this viral structure are preferentially degraded by the combined action of the $\left(2^{\prime}-5^{\prime}\right) A_{n}$ polymerase and RNase $L$ (16). A similar localized activation of RNase $\mathrm{L}$ may account for the degradation of nascent reovirus mRNAs. Some support for this proposal comes from the experiments of Galster and Lengyel (8), who showed that an endonuclease activity is associated with subviral particles of IFN-treated cells that synthesize reovirus mRNAs. A consequence of a localized activation is that nascent viral mRNAs are preferentially cleaved by RNase L. Thus, an antiviral mechanism based on the combined action of the $\left(2^{\prime}-5^{\prime}\right) A_{n}$ polymerase and RNase $\mathrm{L}$ may by itself adequately protect IFN-treated HeLa cells from reovirus infection.

\section{ACKNOWLEDGMENTS}

We are indebted to Donald Nuss for providing us with details of the procedure for Northern blot analysis and for the generous gift of reovirus preparations.

This research was supported by Public Health Service grant AI16076 from the National Institute of Allergy and Infectious Diseases.

\section{LITERATURE CITED}

1. Baglioni, C. 1979. Interferon induced enzymatic activities and their role in the antiviral state. Cell 17:255-264.

2. Baglioni, C., M. A. Minks, and P. A. Maroney. 1978. Interferon action may be mediated by activation of a nuclease by pppA2'p5'A2'p5'A. Nature (London) 273: 684-687.

3. Banerjee, A. K., and A. J. Shatkin. 1970. Transcription in vitro by reovirus-associated ribonucleic acid-dependent polymerase. J. Virol. 6:1-11.

4. Both, G. W., S. Lavi, and A. Shatkin. 1975. Synthesis of all the gene products of the reovirus genome in vivo and in vitro. Cell 4:173-180.

5. Clemens, M. J., and B. R. G. Williams. 1978. Inhibition of cell-free protein synthesis by pppA2'p5'A2'p5'A: a novel oligonucleotide synthesized by interferon-treated $L$ cell extracts. Cell 13:565-572.

6. Derman, E., K. Krauter, L. Walling, C. Weinberger, M. Ray, and J. E. Darnell, Jr. 1981. Transcriptional control in the production of liver-specific mRNAs. Cell 23:731-739.

7. Floyd, R. W., M. P. Stone, and W. K. Joklik. 1974 Separation of single stranded ribonucleic acids by acrylamide-agarose-urea gel electrophoresis. Anal. Biochem. 59:599-609.

8. Galster, R. L., and P. Lengyel. 1976. Formation and 
characteristics of reovirus subviral particles in interferontreated mouse L cells. Nucleic Acids Res. 3:581-598.

9. Grollman, A. P. 1966. Structural basis for inhibition of protein synthesis by emetine and cycloheximide based on an analogy between ipecac alkaloids and glutarimide antibiotics. Proc. Natl. Acad. Sci. U.S.A. 56:1867-1874.

10. Hovanessian, A. G., R. E. Brown, and I. M. Kerr. 1977. Synthesis of low molecular weight inhibitor of protein synthesis with enzyme from interferon-treated cells. $\mathrm{Na}$ ture (London) 268:537-540.

11. Kerr, I. M., and R. E. Brown. 1978. pppA2'p5'A2'p5'A: an inhibitor of protein synthesis synthesized with an enzyme fraction from interferon-treated cells. Proc. Natl. Acad. Sci. U.S.A. 75:256-260.

12. Knight, M., P. J. Cayley, R. H. Silverman, D. H. Wreschner, C. S. Gilbert, R. E. Brown, and I. M. Kerr. 1980. Radioimmune, radiobinding and HPLC analysis of 2-5A and related oligonucleotides from intact cells. $\mathrm{Na}$ ture (London) 288:189-192.

13. Lengyel, P., R. Desrosiers, R. Broeze, E. Slattery, H. Taira, J. Dougherty, H. Samanta, J. Pichon, P. Farrell, L. Ratner, and G. Sen. 1980. Biochemistry of the interferon system, p. 219-226. In D. Schlessinger (ed.), Microbiology-1980. American Society for Microbiology.

14. McMaster, G. K., and G. C. Carmichael. 1977. Analysis of single- and double-stranded nucleic acids on polyacrylamide and agarose gels by using glyoxal and acridine orange. Proc. Natl. Acad. Sci. U.S.A. 74:4835-4838.

15. Minks, M. A., S. Benvin, P. A. Maroney, and C. Baglioni. 1979. Synthesis of 2' 5 '-oligo(A) in extracts of interferontreated HeLa cells. J. Biol. Chem. 254:5058-5064.

16. Nilsen, T. W., and C. Baglioni. 1979. A mechanism for discrimination between viral and host mRNA in interferion-treated cells. Proc. Natl. Acad. Sci. U.S.A. 76:2600 2604.

17. Nilsen, T. W., P. A. Maroney, and C. Baglioni. 1979.
2'5'-oligo(A): a mediator of viral RNA cleavage in interferon-treated cells?, p. 329-339. In H. Koch and D. Richter (ed.), Regulation of macromolecular synthesis by low molecular weight mediators. Academic Press, Inc., New York.

18. Nilsen, T. W., P. A. Maroney, and C. Baglioni. 1981 Double-stranded RNA causes synthesis of $2^{\prime}, 5^{\prime}$-oligo(A) and degradation of messenger RNA in interferon-treated cells. J. Biol. Chem. 256:7806-7812.

19. Perry, R. P. 1962. The cellular sites of synthesis of ribosomal and 4S RNA. Proc. Natl. Acad. Sci. U.S.A. 48:2179-2186.

20. Ratner, L., R. C. Wiegand, P. J. Farrell, G. C. Sen, B. Cabrer, and P. Lengyel. 1978. Interferon, double-stranded RNA and RNA degradation. Fractionation of the endonuclease $_{\text {INT }}$ system into two macromolecular components; role of a small molecule in nuclease activation. Biochem. Biophys. Res. Commun. 81:947-954.

21. Revel, M., H. Kimchi, A. Schmidt, L. Shulman, and Y. Chernajovsky. 1979. Studies on interferon action: synthesis, degradation and biological activity of $\left(2^{\prime}-5^{\prime}\right)$ oligoisoadenylate. In H. Koch and D. Richter (ed.), Regulation of macromolecular synthesis by low molecular weight mediators. Academic Press, Inc., New York.

22. Taylor, J. M., R. Illmensee, and J. Summers. 1976. Efficient transcription of RNA into DNA by avian sarcoma virus polymerase. Biochim. Biophys. Acta 442:324330.

23. Williams, B. R. G., R. R. Golgher, R. E. Brown, C. S. Gilbert, and I. M. Kerr. 1979. Natural occurrence of 2-5A in interferon-treated EMC virus-infected $L$ cells. Nature (London) 282:582-586.

24. Wreschner, D. H., T. C. James, R. H. Silverman, and I. M. Kerr. 1981. Ribosomal RNA cleavage, nuclease activation and 2-5A (ppp $\left.(A 2 \text { ' } p)_{n} A\right)$ in interferon-treated cells. Nucleic Acids Res. 9:1571-1581. 